\title{
The effect of glycosaminoglycans on rat gametes in vitro and the associated signal pathway
}

\author{
Neil Borg and Michael Holland \\ Monash Institute of Medical Research, Centre for Reproduction and Development, 27-31 Wright Street, Clayton, \\ Victoria 3168, Australia \\ Correspondence should be addressed to N Borg; Email: neil.borg.2007@gmail.com
}

\begin{abstract}
The effects of adding the extracellular glycosaminoglycans (GAGs), hyaluronic acid (HA) and chondroitin sulphate (CS) to rat in vitro fertilisation (IVF) media were assessed. Metaphase II (MII) oocytes were also incubated in GAG-supplemented modified rat 1-cell embryo culture medium ( $\mathrm{mR1ECM}+\mathrm{BSA}$ ) for 3 days. Cytoplasmic fragmentation was significantly reduced in mR1ECM + BSA with HA (39.0-48.0\%) compared with the control (82.0\%). In IVF experiments, neither HA (8.0-30.8\%) nor CS (9.7-42.5\%) improved fertilisation rates compared with controls fertilised in M16 (47.2\%) or enriched Krebs-Ringer bicarbonate solution (61.5\%). RT-PCR and Western blot were used to probe for CD44 mRNA and protein in Sprague-Dawley gametes and cumulus cells. CD44 was identified in cumulus cells, suggesting a role for oocyte maturation and cumulus expansion. The CD44 protein was also present on caudal epididymal spermatozoa that were highly stimulated by CS in vitro implicating a role in fertilisation for CS and CD44.

Reproduction (2008) 135 311-319
\end{abstract}

\section{Introduction}

Glycosaminoglycans (GAGs) are negatively charged polysaccharide chains of alternate lengths that have a moderate diversity of form (Ruoslahti \& Yamaguchi 1991, Kim et al. 2001). GAGs are synthesised by many somatic cell types and have functions in cell-to-cell adhesion (Kosaki et al. 1999), following migration, proliferation (Camenisch et al. 2002) and (Itano et al. 2002, Legg et al. 2002) differentiation (Hamashima 1982). They are extensively distributed within the extracellular matrix of many tissues (Camaioni et al. 1993, Bose \& Masellis 2005). Hyaluronic acid (HA) or hyaluronan is a non-sulphated, linear GAG that comprises alternating units of D-glucuronic acid and $\mathrm{N}$-acetylglucosamine linked by ß1-3 and 31-4 glycosidic bonds (Yokoo et al. 2002a, Toyokawa et al. 2005). Chondroitin sulphate A (CS) is made of a repeating D-glucuronic acid and $\mathrm{N}$-acetylgalactosamine disaccharide with the same glycosidic linkages as HA and is sulphated (Sakai et al. 2007). HA (Kano et al. 1998, Kimura et al. 2002, Kim et al. 2005) and CS Jensen \& Zachariae 1958, Lee \& Ax 1984, Kano et al. 1998) are GAGs that have been observed to have roles in reproductive physiology.

$\mathrm{HA}$ is abundant in the uterine, oviductal and follicular fluids of murine (Sato et al. 1987), porcine (Archibong et al. 1989), bovine (Lee \& Ax 1984) and human (Suchanek et al. 1994, Hamamah et al. 1996, Ohta et al. 2001) species.
Furthermore, HA has been proposed to be an essential player of macaque spermatozoa capacitation and fertilisation (Cherr et al. 1999). CS has been identified in human (Hamamah et al. 1996) and porcine (Ax \& Ryan 1979, Yanagishita et al. 1979) follicular fluid. Hydrolysation of rat granulosa cells with chondroitinase $\mathrm{ABC}$ revealed that CS is the major GAG of rat granulosa cells (Yanagishita \& Hascall 1979).

The synthesis of HA occurs at the cell membrane by HA synthases (HAS; Watanabe \& Yamaguchi 1996, Spicer et al. 1997 b, Weigel etal. 1997). There are three isoenzymes that facilitate this process: HAS1 (Watanabe \& Yamaguchi 1996), HAS2 (Salustri et al. 1989, 1992) and HAS3 (Spicer et al. 1997a). HAS1 protein has been identified in equine cumulus cells (Marchal et al. 2003). HAS2 mRNA transcripts have been detected in bovine oocyte-cumulus complexes (OCC; Schoenfelder \& Einspanier 2003) and murine (Salustri et al. 1989, Fulop et al. 1997) and porcine cumulus cells (Kimura et al. 2002). mRNA transcripts for HAS3 are expressed in bovine OCC (Schoenfelder \& Einspanier 2003) and porcine metaphase II (MII) oocytes (Kimura et al. 2002). Additionally, HAS3 protein has been identified in equine cumulus cells (Marchal et al. 2003).

There have been six glycosyltransferases identified that regulate the synthesis of CS (Sakai et al. 2007) within the Golgi apparatus (Silbert \& Freilich 1980). These are CS synthase-1 (CSS-1; Kitagawa et al. 2001), CSS-2 (Yada et al. 
2003a), CSS-3 (Yada et al. 2003b), CS N-acetylgalactosaminetransferase-1 (CSGalNAcT-1; Gotoh et al. 2002b, Uyama et al. 2002) and CSGalNAcT-2 (Sato et al. 2003) and CS glucuronyltransferase (CSGlcAT; Gotoh et al. 2002a). CSS have been reported to stimulate cumulus expansion and HAS activity in mice (Eppig 1981).

The primary receptor for $\mathrm{HA}$ is the cell surface glycoprotein CD44, which also functions as a receptor for CS (Culty et al. 1990). CD44 is thought to interact with $\mathrm{HA}$ via a highly conserved transmembrane region (Isacke 1994, Entwistle et al. 1996, Liu et al. 1998, Shi etal. 2001). This receptor has been identified on a wide range of cells that include epithelial cells (Alho \& Underhill 1989), macrophages (Green et al. 1988a, 1988b) and lymphocytes (Lesley et al. 1993). The CD44 receptor has also been identified in bovine OCC (Schoenfelder \& Einspanier 2003) and pre-implantation embryos (Furnus et al. 2003), porcine cumulus cells (Kimura et al. 2002, Yokoo et al. 2002a, 2002b, 2007), germinal vesicle-intact and MII oocytes and cleaved parthenotes (Toyokawa et al. 2005).

The use of extracellular HA and CS for in vitro maturation (IVM), in vitro culture (IVC) and in vitro fertilisation (IVF) media is documented in mammalian species, including canine (Kawakami et al. 2000), porcine (Kano et al. 1998), bovine (Lenz et al. 1983, Lee et al. 1986, Jang et al. 2003, Therien et al. 2005) and human (Eriksen et al. 1994, Hamamah et al. 1996) but not the rat. These studies reported significant influences on spermatozoa (increased motility and incidence of acrosome exocytosis), oocytes (elevated IVF rates) and pre-implantation embryos (improved rates of development in IVC) in GAG-supplemented media.

Here, we report on the ability of GAGs, HA and CS in a rat IVF system to improve overall fertilisation outcomes and potentially suppress spontaneous activation. Furthermore, we report on the expression of CD44 in Sprague-Dawley gametes and MII cumulus cells.

\section{Results \\ Incubation of MII oocytes in GAG-supplemented mR1ECM+s-BSA}

To examine the influence of the GAGs on MIl oocytes, mR1ECM+BSA was supplemented with HA and CS. Denuded oocytes were subsequently incubated over a 72-h time frame with inspection every $24 \mathrm{~h}$. Figure 1 displays the changes to MII cytoplasmic cohesion over a 72-h period in standard mR1ECM+BSA (control) or supplemented with CS or HA at 250 or $500 \mu \mathrm{g} / \mathrm{ml}$. All denuded MII oocytes had a normal-appearing morphology at the start of the experiment. After $24 \mathrm{~h}$, the proportion of morphologically normal oocytes was high $(>79 \%)$ for all media groups (Fig. 1). At $24 \mathrm{~h}$, parthenotes represented only a small, non-significant proportion of oocytes in all groups.

At $48 \mathrm{~h}$, the number of MII oocytes with a normal appearance was significantly higher in HA-500 (Fig. 1E, $P<0.0001 ; 47 \%$ ) and HA-250 (Fig. 1D, $P<0.0001 ; 36 \%$ ).
Additionally, a significant increase was observed for CS250 (Fig. 1B, $P<0.05 ; 26 \%$ ). This effect correlated with the significantly lower numbers of fragmented oocytes (Fig. 1D and $\mathrm{E}, 36 \% ; 51 \%, P<0.001-0.0001)$ compared with the control (Fig. 1A, 79\%). There was a significant number of cleaved parthenotes present in CS-500 (Fig. 1C, 25\%; $P<0.001$ ) compared with the mR1ECM control (Fig. 1A).

By $72 \mathrm{~h}$, there were significantly fewer fragmented oocytes for mR1ECM+BSA supplemented with HA (Fig. 1D and $\mathrm{E}, 36-39 \%, P<0.0001$ ) compared with the control (Fig. 1). Any positive effect of CS by this time had ended (Fig. 1B and C). Numbers of two-cell parthenotes were significantly higher in CS-500 (Fig. 1C, $20 \% ; P<0.05)$ and higher for all GAG-supplemented media (Fig. 1B-E, 8-16\%) compared with the control (Fig. 1A, 6\%).

\section{Spermatozoa motility}

At the onset of co-incubation, all dishes were inspected to ensure that spermatozoa appeared healthy to the naked eye. CS-supplemented media contained greater numbers of visually motile caudal epididymal spermatozoa. While not as active, spermatozoa in all other media still presented a very healthy motility prior to insemination (Table 1).

At the end of co-incubation, CS-complemented media contained higher numbers of motile spermatozoa. While all spermatozoa were now sluggish, this effect was the most reduced in media with CS. Spermatozoa in controls were predominantly dead at this time point, whereas HA-supplemented media had some activity.

\section{IVF of MII oocytes in GAG-supplemented medium}

A control IVF experiment was run alongside IVF-GAG experiments to confirm normal oocyte and spermatozoa function (Table 2). All experiments were conducted with cumulus-intact oocytes as in previous IVF experiments. Thus, unlike the incubation experiments, MII oocytes were not denuded. The control outcomes observed were reasonably consistent with past laboratory experiments. EKRB (65.8\%) and M16 (54.8\%) had substantially higher numbers of fertilised embryos than mR1ECM+BSA (36.7\%; Table 2).

GAG supplementation significantly decreased fertilisation rates in M16-HA (13.5\%; $P<0.001)$, EKRB-CS (14.3\%; $P<0.05)$, mR1ECM-CS $(9.7 \% ; P<0.01)$ and mR1ECM-HA $(8.0 \% ; P<0.001 ;$ Table 3) compared with the controls $(\mathrm{M} 16=47.2 \%$ and $\mathrm{EKRB}=61.5 \%)$. The media, M16-CS (42.5\%) and to a lesser extent EKRB-HA (30.8\%), displayed levels of fertilisation similar to their respective control media (Table 3). Rates of polyspermic fertilisation were higher than previously observed in IVF experiments but rates were generally similar to the controls. 

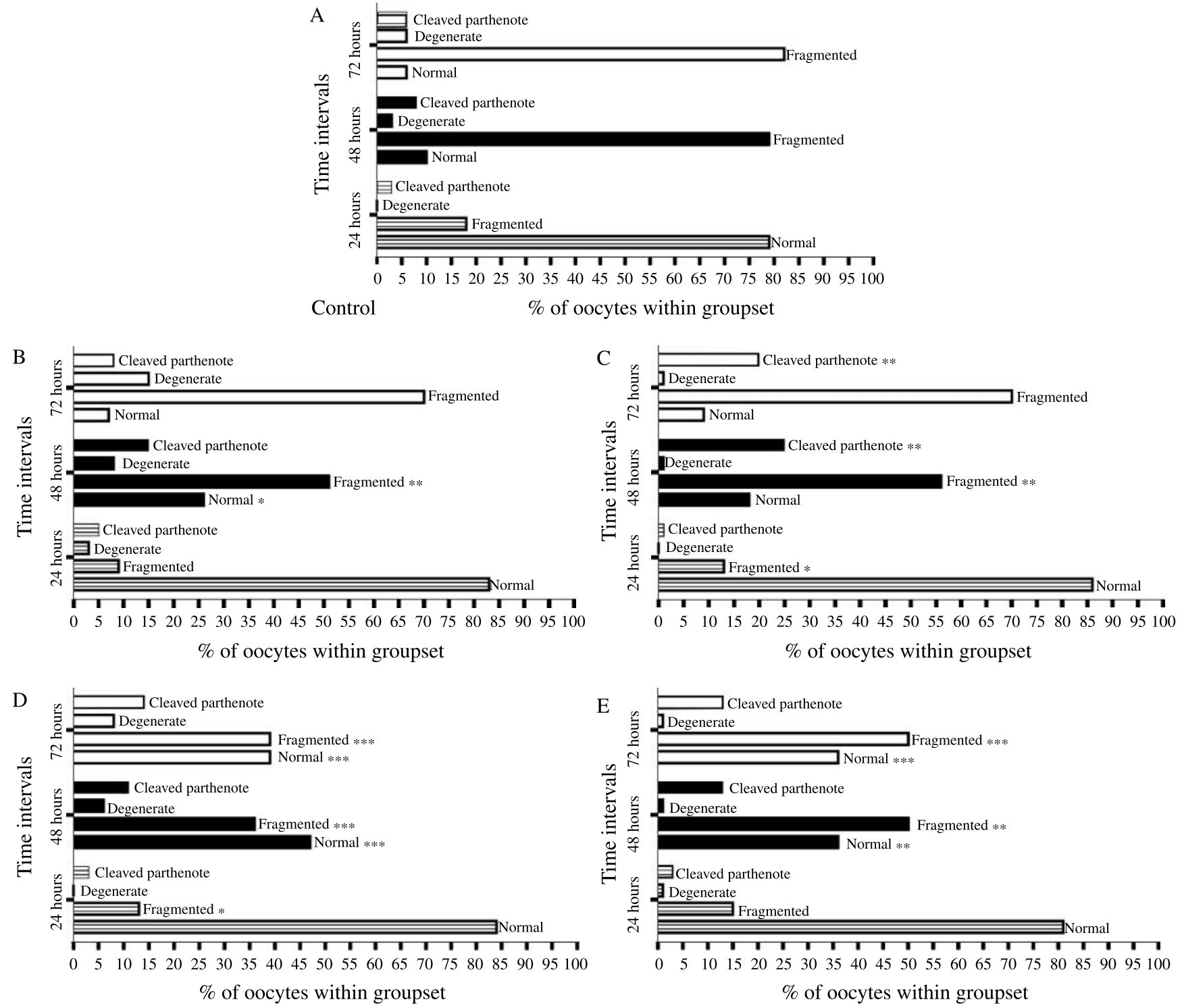

Figure 1 Fragmentation suppression in denuded, zona pellucida (ZP) intact rat Mll oocytes incubated in mR1ECM+BSA (310 mOsm) with/without GAG supplementation at $37^{\circ} \mathrm{C}$ in a $5 \% \mathrm{CO}_{2}$ atmosphere for $72 \mathrm{~h}$. Samples $(n=100)$ were compared with the control value $(n=100)$ every $24 \mathrm{~h}$ over the 3-day period; ${ }^{*} P \leq 0.05,{ }^{* *} P<0.001,{ }^{* * *} P<0.0001$ indicate statistical significance to the standard mR1ECM-BSA control for the respective rows. (A) mR1ECM+BSA (control); (B) mR1ECM+BSA (CS $250 \mu \mathrm{g} / \mathrm{ml}) ;(\mathrm{C}) \mathrm{mR} 1 \mathrm{ECM}+\mathrm{BSA}$ (CS $500 \mu \mathrm{g} / \mathrm{ml}) ;$ (D) mR1ECM+BSA (HA $250 \mu \mathrm{g} / \mathrm{ml})$ and (E) $\mathrm{mR} 1 \mathrm{ECM}+\mathrm{BSA}(\mathrm{HA} 500 \mu \mathrm{g} / \mathrm{ml})$.

\section{Secondary binding of spermatozoa to the embryo}

Examination of Hoechst-stained embryos and oocytes revealed no prevalence of secondary binding by spermatozoa among the various groups (data not shown). The presence of GAGs did not seem to influence this trait of IVF in any specific manner.

\section{mRNA expression of the $H A$ receptor $C D 44$ in Sprague-Dawley gametes and cumulus cells}

RT-PCR revealed a CD44 mRNA transcript present in cumulus cells collected from MII oocytes obtained from superovulated immature female rats (Fig. 2). The band obtained corresponded to the predicted amplicon size (1090 bp). Both MII oocytes and caudal epididymal spermatozoa showed no presence of the CD44 transcript. All samples were also probed with primers for adenyl cyclase III (ACIII) as a control gene to confirm that mRNA was obtained from the extraction procedure. The ACIII PCR product was present for all samples and the liver positive control (Fig. 2).

\section{CD44 protein expression in Sprague-Dawley gametes and MII oocyte cumulus cells}

The CD44 mAb showed the presence of a protein band $(\sim 50 \mathrm{kDa})$ present in both caudal epididymal 
Table 1 In vitro fertilisation (IVF) medium composition.

\begin{tabular}{|c|c|c|c|}
\hline & $\begin{array}{c}\text { mR1ECM } \\
+ \text { BSA } \\
\end{array}$ & EKRB & M16 \\
\hline \multicolumn{4}{|l|}{ Stock A } \\
\hline $\mathrm{NaCl}$ & $110.0 \mathrm{mM}$ & $119.4 \mathrm{mM}$ & $94.66 \mathrm{mM}$ \\
\hline $\mathrm{KCl}$ & $3.2 \mathrm{mM}$ & $4.8 \mathrm{mM}$ & $4.78 \mathrm{mM}$ \\
\hline $\mathrm{MgSO}_{4} \cdot 7 \mathrm{H}_{2} \mathrm{O}$ & - & $1.2 \mathrm{mM}$ & $1.19 \mathrm{mM}$ \\
\hline $\mathrm{MgCl}_{2}$ & $0.5 \mathrm{mM}$ & - & - \\
\hline $\begin{array}{l}\text { Na lactate } \\
\left(\mathrm{C}_{3} \mathrm{H}_{5} \mathrm{NaO}_{3}\right)\end{array}$ & $10.0 \mathrm{mM}$ & $21.0 \mathrm{mM}$ & $23.28 \mathrm{mM}$ \\
\hline Glucose $\left(\mathrm{C}_{6} \mathrm{H}_{12} \mathrm{O}_{6}\right)$ & $7.5 \mathrm{mM}$ & $5.0 \mathrm{mM}$ & $5.56 \mathrm{mM}$ \\
\hline Stock B & & & \\
\hline \multicolumn{4}{|l|}{ Stock C } \\
\hline $\begin{array}{l}\text { Na pyruvate } \\
\left(\mathrm{C}_{3} \mathrm{H}_{3} \mathrm{O}_{3} \mathrm{Na}\right)\end{array}$ & $0.5 \mathrm{mM}$ & $0.25 \mathrm{mM}$ & $0.33 \mathrm{mM}$ \\
\hline \multicolumn{4}{|l|}{ Stock D } \\
\hline $\mathrm{CaCl}_{2}$ & $2.0 \mathrm{mM}$ & $1.0 \mathrm{mM}$ & $1.71 \mathrm{mM}$ \\
\hline \multicolumn{4}{|l|}{ Stock P } \\
\hline $\mathrm{KH}_{2} \mathrm{PO}_{4}$ & - & $1.2 \mathrm{mM}$ & $1.19 \mathrm{mM}($ stock $\mathrm{A})$ \\
\hline $\begin{array}{l}\text { MEM essential amino } \\
\text { acids }\end{array}$ & 1:100 (v:v) & - & - \\
\hline $\begin{array}{l}\text { MEM non-essential } \\
\text { amino acids }\end{array}$ & $1: 200(v: v)$ & - & - \\
\hline BSA & $4 \mathrm{mg} / \mathrm{ml}$ & $3 \mathrm{mg} / \mathrm{ml}$ & $4 \mathrm{mg} / \mathrm{ml}$ \\
\hline
\end{tabular}

spermatozoa and cumulus cells obtained from ovulated MII oocytes (Fig. 3). The presence of a CD44 protein in the sperm sample was contradictory to the RT-PCR result (Fig. 2) that did not detect an mRNA transcript. Faint signals were present in the liver controls.

\section{Discussion}

In this study, the GAGs HA and CS were able to suppress fragmentation in denuded MII oocytes. HA was more effective at this than CS implicating a role for HA and CD44. RT-PCR and Western blot of MII oocytes did not detect CD44 mRNA transcripts or an expressed CD44 protein. However, CD44 was identified in cumulus cells obtained from MII oocytes obtained by superovulation. CD44 expression was influenced by equine chorionic gonadotrophin in porcine cumulus cells during IVM (Kimura et al. 2002). Furthermore, it is documented that follicle stimulating hormone and luteinizing hormone (LH) increase CD44 expression in bovine

Table 2 In vitro fertilisation (IVF) outcomes for cumulus-intact, ZP intact rat metaphase II (MII) oocytes inseminated with pre-incubated rat caudal epididymal spermatozoa $\left(7.5 \times 10^{5} \mathrm{sp} / \mathrm{ml}, 6.0 \mathrm{~h}\right)$ in standard IVF media $(310 \mathrm{mOsm})$ at $37^{\circ} \mathrm{C}$ in a $5 \% \mathrm{CO}_{2}$ atmosphere for $11.5 \mathrm{~h}$.

\begin{tabular}{llll}
\hline Control & M16 \% $(n)$ & EKRB \% $(n)$ & mR1ECM+BSA \% $(n)$ \\
\hline$n$ & $100(31 / 31)$ & $100(38 / 38)$ & $100(30 / 30)$ \\
Unfertilised & $16.1(5 / 31)$ & $10.5(4 / 38)$ & $46.6(14 / 30)^{*,}$, \\
Normal & $54.8(17 / 31)$ & $65.8(25 / 38)$ & $36.7(11 / 30)$ \\
$\begin{array}{c}\text { fertilisation } \\
\text { Polyspermic }\end{array}$ & $29.0(9 / 31)$ & $23.6(9 / 38)$ & $16.7(5 / 30)$ \\
\hline
\end{tabular}

${ }^{*} P \leq 0.05$ indicates statistical significance to $M 16$ for the row.

" $P<0.001$ indicates statistical significance to EKRB for mR1ECM+BSA.
OCC (Schoenfelder \& Einspanier 2003). Chorionic gonadotrophin is known to induce an endogenous $\mathrm{LH}$ surge in superovulated female rats soon after its administration (Goh et al. 1992). This suggests that HA and CD44 have a role to play in regulating the integrity of oocyte cytoplasm during cumulus expansion and post-ovulation as seen by the presence of a CD44 mRNA transcript in cumulus cells obtained from superovulated MII oocytes.

After granulosa cell (GC) differentiation into mural GCs and oocyte-bound cumulus cells and the subsequent $\mathrm{LH}$ surge, expansion of cumulus cells is essential to the final stages of maturation (Dekel \& Phillips 1979, Kimura et al. 2002, Yokoo et al.2007). During this process of expansion, $\mathrm{HA}$ is actively synthesised and accumulates in the cumulus matrix (Dekel \& Phillips 1979, Eppig 1979, Salustri et al. 1990). The ability of HA to suppress oocyte fragmentation has been observed in murine (Sato et al. 1987), bovine (Sato et al. 1988) and porcine (Sato et al. 1994) species. The incubation experiments in this study implicate a role for the CD44-HA signal pathway in oocyte maturation and/or maintenance prior to fertilisation. The ability of $\mathrm{HA}$ and CS to suppress oocyte fragmentation in vitro supports a role for HA within the extracellular matrix of cumulus cells.

IVF experiments in media supplemented with HA or CS did not improve fertilisation rates above those of controls, suggesting that there is a limit to their usefulness in vitro. Indeed, it seemed that the two GAGs promoted spontaneous activation of MII oocytes. Resumption of meiosis in MII oocytes is controlled by maturation promoting factor protein that acts to regulate MAP kinase (MAPK) via activation of an oocyte exclusive kinase. The active c-mos kinase promotes MAP kinase (MEK) phosphorylation of MAPK and its activation (Lu et al. 2002, Josefsberg et al. 2003).

CD44 has been observed to induce proliferation in colon cancer cells (Singh et al. 2006) and mouse thymoma EL4 cells via activation of MAPK (Marhaba et al. 2005). Furthermore, there is a large body of evidence to show that HA and CD44 are active in many signal pathways (Kobayashi et al. 2002, Roscic-Mrkic et al. 2003, Bourguignon et al. 2005, 2006, Lugli et al. 2006, Shi et al. 2006). The primer sequence (Kon et al. 2006) for CD44 in RT-PCR targeted the transcript for the whole protein. There are over 30 exons present in the entire CD44 sequence that through alternative mRNA splicing generates numerous isoforms (Screaton et al. 1992, Tolg et al. 1993, Bajorath 2000). There is a reasonable likelihood that one of these may be present in rat oocytes that could function to induce parthenogenesis in vitro due to extracellular HA or CS stimulation. This hypothesis would support the effect of HA and CS on rat MII oocytes and requires further investigation.

The CD44 protein detected in spermatozoa and cumulus cells was $\sim 50 \mathrm{kDa}$ in mass. The apparent standard for CD44 is a protein in the range of $85-90 \mathrm{kDa}$ (Lesley \& Hyman 1998, Yokoo et al. 2002b). The amino 
Table 3 In vitro fertilisation (IVF) outcomes for cumulus intact, ZP intact rat metaphase II (MII) oocytes inseminated with pre-incubated rat caudal epididymal spermatozoa $\left(7.5 \times 10^{5} \mathrm{sp} / \mathrm{ml}, 6.0 \mathrm{~h}\right)$ in M16 $(310 \mathrm{mOsm})$ with/without $500 \mu \mathrm{g} / \mathrm{ml}$ glycosaminoglycan (GAG)-supplementation at $37^{\circ} \mathrm{C}$ in a $5 \% \mathrm{CO}_{2}$ atmosphere for $11.5 \mathrm{~h}$.

\begin{tabular}{|c|c|c|c|c|c|c|c|c|}
\hline $\begin{array}{l}\text { Capacitation and } \\
\text { co-incubation }\end{array}$ & $\begin{array}{c}\text { M16 control } \\
\%(n)\end{array}$ & $\begin{array}{c}\text { EKRB control } \\
\%(n)\end{array}$ & $\begin{array}{c}\text { M16 (CS) } \\
\%(n)\end{array}$ & $\begin{array}{c}\text { M16 (HA) } \\
\%(n)\end{array}$ & $\begin{array}{c}\text { EKRB (CS) } \\
\quad \%(n)\end{array}$ & $\begin{array}{l}\text { EKRB (HA) } \\
\quad \%(n)\end{array}$ & $\begin{array}{l}\text { mR1ECM+ } \\
\text { BSA (CS) } \\
\%(n)\end{array}$ & $\begin{array}{l}\text { mR1ECM+ } \\
\text { BSA (HA) } \\
\%(n)\end{array}$ \\
\hline$n$ & 53 & 39 & 40 & 37 & 14 & 26 & 31 & 25 \\
\hline Unfertilised & $28.3(15 / 53)$ & $5.1(2 / 39)^{*}$ & $27.5(11 / 40)^{\S}$ & $\begin{array}{l}86.5 \\
(32 / 37)^{ \pm, 9}\end{array}$ & $64.3(9 / 14)^{*, \pi}$ & $34.6(9 / 26)^{\|}$ & $\begin{array}{l}83.9 \\
(26 / 31)^{\ddagger \text {, }}\end{array}$ & $\begin{array}{l}92.0 \\
(23 / 25)^{ \pm, \pi}\end{array}$ \\
\hline Normal fertilisation & $47.2(25 / 53)$ & $61.5(24 / 39)$ & $42.5(17 / 40)$ & $13.5(5 / 37)^{+, \pi}$ & $14.3(2 / 14)^{\S}$ & $30.8(8 / 26)$ & $9.7(3 / 31)^{+, \pi}$ & $8.0(2 / 25)^{t, \pi}$ \\
\hline Polyspermic & $24.5(13 / 53)$ & $33.3(13 / 39)$ & $30.0(12 / 40)$ & $0.0(0 / 37)^{t, 9}$ & $21.4(3 / 14)$ & $34.6(9 / 26)$ & $6.5(2 / 31)^{\S}$ & $0.0(0 / 25)^{*, \|}$ \\
\hline
\end{tabular}

${ }^{*} P \leq 0.05,{ }^{\dagger} P<0.001,{ }^{\ddagger} P<0.0001$ indicate statistical significance to $M 16$ for the respective rows. ${ }^{\S} P \leq 0.05,{ }^{\|} P<0.001,{ }^{\mathbb{T}} P<0.0001$ indicate statistical significance to EKRB for the respective rows.

acid sequence for CD44 predicts a band of $40 \mathrm{kDa}$, yet bands ranging from 73 to $88 \mathrm{kDa}$ were detected in porcine cumulus cells (Yokoo et al. 2002b). The level of CD44 glycosylation is thought to be responsible for the apparent differences in mass (Borland et al. 1998).

The CD44 mRNA transcript was also absent in caudal epididymal spermatozoa yet immunoblotting detected the protein. It is probable that the CD44 protein is bound to spermatozoa during maturation as are other proteins (Cuasnicu et al. 1990, Cohen et al. 2000). Furthermore, in the presence of extracellular CS, sperm motility was greatly enhanced in human (Eriksen et al. 1994, Hamamah et al. 1996) and canine (Kawakami et al. 2000) spermatozoa motility. CD44 is a receptor for CS (Culty et al. 1990) which has been identified in human follicular fluid (Hamamah et al. 1996) and canine oviductal and uterine fluids (Kawakami et al. 2000). Additionally, CS is reported to be the primary GAG within rat granulosa cells (Yanagishita \& Hascall 1979). The presence of CS within uterine or oviductal fluids or the OCC matrix may act to stimulate spermatozoa so that they can reach the zona pellucida.

In conclusion, CD44 is present in rat cumulus cells and caudal epididymal spermatozoa, suggesting roles in cumulus expansion, oocyte maturation and motility stimulation. The protein detected suggests a low level of glycosylation or a specific isoform. Further investigation is required to assess the mRNA transcripts for CD44 isoforms in MIl oocytes and pre-implantation embryos. The identification of HAS is also required.

\section{Materials and Methods}

All reagents were purchased from the Sigma-Aldrich Chemical Company unless otherwise specified. BSA, protein supplement, was the Albumax I liposaccharide-rich variety (Gibco, Invitrogen). Cultureware was obtained from Becton-Dickinson (BD; Melbourne, Australia) unless otherwise specified.

\section{Animals}

Rats were obtained from the Monash University Central Animal Services (MUCAS, Clayton, Victoria, Australia) outbred Sprague-Dawley (OBSD) - specific pathogen-free (spf) colony.
Rats were housed at the Block B animal house facility, Monash Medical Centre in standard rat sized boxes (one male per box, five females per box) with high top cage lids. Rats were kept under a standard $12 \mathrm{~h}$ light:12 h darkness cycle (0800:2000 h) and provided water and food ad libitum. The holding room temperature was maintained at $22^{\circ} \mathrm{C}$ with an average humidity of $50 \%$. This study was approved by the Monash Medical Centre Animal Ethics Committee.

\section{Media}

All media used in these experiments were made from a specific salt solutions with additional compounds added at different concentrations (Table 1). The rat-specific medium, modified rat 1-cell embryo culture medium, mR1ECM+BSA (Oh et al. 1998), was used for all MII oocyte incubations and as an IVF medium. In addition the media, namely enriched Krebs-Ringer bicarbonate (EKRB; Bendahmane et al. 2002) and M16 (Whittingham 1971) were used in IVF experiments. The osmolarity of all IVF media was set at $310 \mathrm{mOsm}$ for all experiments.

\section{Caudal epididymal spermatozoa collection and vitro capacitation}

Spermatozoa were obtained from the caudal epididymides of sexually mature (3-4 months old) OBSD males. Rat MII oocytes were fertilised following standard IVF methodology (Toyoda \& Chang 1974) with some minor modification. The caudae were washed in pre-warmed calcium $\left(\mathrm{Ca}^{2+}\right) /$ magnesium $\left(\mathrm{Mg}^{2+}\right)$-free Dulbecco's PBS (DPBS) and were immediately placed into

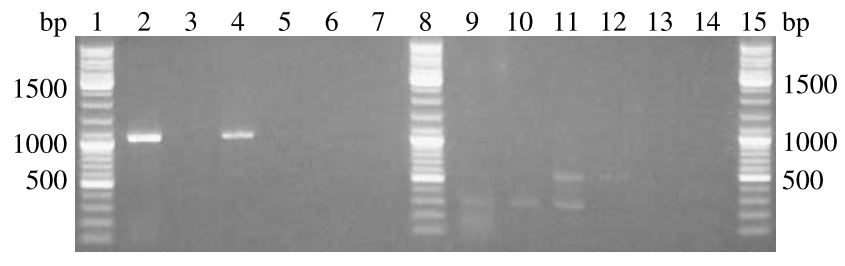

Figure 2 Expression of CD44 mRNA transcripts in Sprague-Dawley gametes and MII oocyte cumulus cells. Lanes 2 and 9, rat liver (positive control); lanes 3 and 10, MII oocyte; lanes 4 and 11, cumulus cells; lanes 5 and 12, caudal epididymal sperm; lanes 6 and 13, RT blank (negative control); lanes 7 and 14, PCR blank (negative control); lanes 1, 8 and 15, Generuler Base pair Standard. 


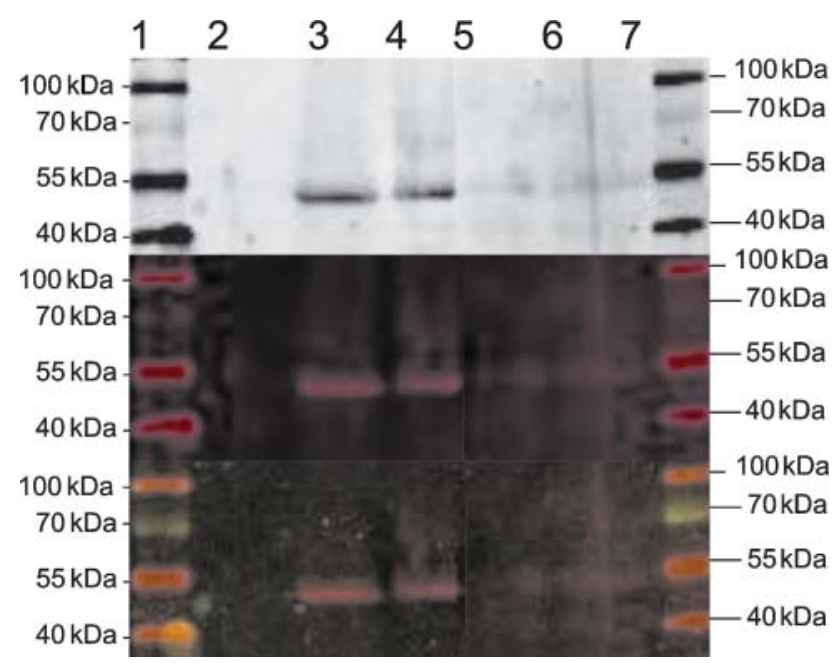

Figure 3 Expression of CD44 protein in Sprague-Dawley gametes and MII oocyte cumulus cells Lane 2, MII oocyte; lane 3, caudal epididymal sperm; lane 4, cumulus cells; lanes 5 and 6, positive control, lanes 1 and 7 , protein molecular weight standard.

standard mR1ECM+BSA, EKRB or M16 for 5 min to facilitate sperm dispersal. A sperm count was conducted to produce a working concentration of $7.5 \times 10^{5}$ spermatozoa per $\mathrm{ml}$. Dishes were subsequently returned to the incubator for a 6-h incubation period to facilitate capacitation $\left(37^{\circ} \mathrm{C}, 5 \% \mathrm{CO}_{2}\right)$.

\section{MII oocyte collection}

MII-stage oocytes were obtained from sexually immature (24-days old) females superovulated with pregnant mare's serum gonadotrophin (10-15i.u. i.p.) at $0 \mathrm{~h}$ and human chorionic gonadotrophin (hCG; 10-15i.u.) at $48 \mathrm{~h}$ by i.p. injection. OCC were immediately transferred to dishes for specific experiments.

\section{Denuding of MII oocytes}

To prepare MII oocytes for incubation in GAG-supplemented mR1ECM+BSA, the surrounding cumulus matrix was removed. OCC were placed into HEPES-buffered mR1ECM+BSA supplemented with hyaluronidase (100 i.u./ml) for $5 \mathrm{~min}$, after which the oocytes were washed in clean HEPES-buffered $\mathrm{mR} 1 \mathrm{ECM}+\mathrm{BSA}$. Oocytes were subsequently transferred to mR1ECM+BSA with/without GAGs.

\section{Incubation of MII oocytes in GAG-supplemented mR1ECM+BSA}

Oocytes were placed into a $400 \mu \mathrm{l}$ drop of pre-equilibrated mR1ECM-BSA $\left(37{ }^{\circ} \mathrm{C}, 5 \% \mathrm{CO}_{2}\right)$. Standard mR1ECM+BSA was the control medium for incubation experiments. The mR1ECM+BSA was supplemented with HA or CS at 250 or $500 \mu \mathrm{g} / \mathrm{ml}$. All dishes were placed into an incubator $\left(37^{\circ} \mathrm{C}, 5 \%\right.$ $\mathrm{CO}_{2}$ ) for $72 \mathrm{~h}$ and their status checked every $24 \mathrm{~h}$.

\section{IVF of MII oocytes in GAG-supplemented media}

OCC designated for IVF were immediately transferred to their respective insemination medium after collection. The insemination dish with spermatozoa $\left(3.0 \times 10^{5}\right.$ in $\left.400 \mu \mathrm{l}\right)$ and OCC present was returned to the incubator $\left(37^{\circ} \mathrm{C}, 5 \% \mathrm{CO}_{2}\right.$ in air) for an $11.5-\mathrm{h}$ co-incubation period.

\section{Primer sequence}

To probe samples for CD44 mRNA transcripts, the forward (F) and reverse (R) sequences described by Kon et al. (2006) were used. These sequences would yield an amplicon 1095 bp in size:

\section{F: CCCGAATTCATGGACAAGGTTTGGTGGCA R: CCCGAATTCCTACACCCCAATCTTCATAT}

To confirm the presence of mRNA during RT, adenyl cyclase III was selected to act as a control gene as its presence had previously been identified in rat caudal epididymal spermatozoa (Wade et al. 2003). Additionally, it was probable that this particular splice variant would be present in rat MII oocytes and liver. These sequences would yield an amplicon 290 bp in size:

\section{F: GACAACCGGGATAGAGCTGG \\ R: CTGCTGTCAGTGCCATTGAGC}

\section{mRNA isolation}

The isolation of mRNA from caudal epididymal spermatozoa and MII oocytes was achieved with the Dynal Dynabead mRNA purification kit (Invitrogen). Oocytes were collected in $5 \mu \mathrm{l}$ mRNA lysis buffer (485.5 $\mu$ I DEPC water, $25 \mu$ l dithiothreitol (DTT), $4 \mu$ I IGEPAL (MP Biomedicals Inc., Melbourne, Australia) and $12.5 \mu \mathrm{l}$ RNAseout (Invitrogen) and immediately snap frozen in liquid nitrogen $\left(\mathrm{N}_{2(\mathrm{l})}\right)$ and stored at $-80{ }^{\circ} \mathrm{C}$ until required. Spermatozoa was collected as described above on the day of RT-PCR and kept in DPBS for use.

The mRNA extracted from rat liver to act as a positive control was done by the Trizol (Invitrogen) method to the specifications of the manufacturer.

\section{RT-PCR}

RT of mRNA samples to produce cDNA was done in a RT solution; $19 \mu \mathrm{l}$ Ultrapure DNase/RNase-free distilled water, $8 \mu \mathrm{l}$ $5 \times$ buffer (Superscript III kit, Invitrogen), $2 \mu$ random primers (1:10 dilution; Invitrogen), $2 \mu$ l of $10 \mathrm{mM}$ dNTP (Fisher Biotech, Perth, Western Australia), $2 \mu \mathrm{l}$ of $0.1 \mathrm{mM}$ DTT (Superscript III kit, Invitrogen) and $2 \mu \mathrm{l}$ RNAseout. Immediately prior to RT, $2 \mu$ Superscript III was added to the sample. The rat liver control RT to act as a positive control was obtained by the Superscript II method to the specifications of the manufacturer.

PCR of samples was performed in a PCR solution; $33.8 \mu \mathrm{l}$ DNase/RNase-free distilled water, $5 \mu \mathrm{l}$ of $2 \mathrm{mM} d \mathrm{NTP}$, $5 \mu \mathrm{l}$ of $10 \times$ PCR buffer, $3 \mu \mathrm{l}$ of $1.5 \mathrm{mM} \mathrm{MgCl}_{2}, 1 \mu \mathrm{l}$ forward primer (1:32.3 dilution), $1 \mu \mathrm{l}$ reverse primer (1:32.3 dilution), $0.2 \mu \mathrm{l}$ Taq polymerase (\#TAQ-3,Fisher Biotech) and $1 \mu \mathrm{l}$ sample cDNA. 


\section{Protein extraction}

Spermatozoa were collected as described above in DPBS and the solution transferred to a Centricon YM-100 centrifugal filter device (Millipore, Melbourne, Australia) and the manufacturer's instructions were followed to remove salts and isolate spermatozoa. The spermatozoa pellet was transferred into $400 \mu \mathrm{l}$ mammalian protein extraction reagent (M-PER; Pierce, Sydney, Australia) with $5 \mu \mathrm{l}$ Calbiochem Protease Inhibitor Cocktail set III. The spermatozoa sample was constantly shaken for $4 \mathrm{~h}$ at RT.

MII oocytes were collected and denuded as described in Leibovitz L-15 tissue culture medium (Gibco, Invitrogen) supplemented with $1 \mathrm{mg} / \mathrm{ml}$ PVA. Rat liver was homogenised and protein extracted in the same manner as spermatozoa with $\mathrm{M}-\mathrm{PER}$, snap frozen in $\mathrm{N}_{2(1)}$ and kept at $-80{ }^{\circ} \mathrm{C}$ until required for electrophoresis.

\section{Electrophoresis and electrotransfer}

Protein samples were separated on a $12 \%$ bis-acrylamide gel in a Bio-Rad Mini-Protean 3 cell as specified by the manufacturer. To prepare samples for probing with a CD44 MAB (mAb), the $12 \%$ gel was prepared according to instructions for the Immobilon transfer polyvinylidene difluoride membrane (Millipore).

\section{Western blot}

Following electrotransfer of proteins, the membrane was blocked and blotted with mouse anti-ratCD44 mAb (PharMingen, BD Biosciences, Sydney, Australia) following the methods for the LI-COR Odyssey infrared imaging system. The primary antibody was used at a ratio of 1:500 in a Tris-buffered saline solution with $0.2 \%$ Tween-20.

\section{Hoechst 33258 staining}

To evaluate sperm penetration and pronuclei formation postinsemination, oocytes were fixed in $4 \%$-paraformaldehyde for a minimum period of $12 \mathrm{~h}$ at $4{ }^{\circ} \mathrm{C}$. Oocytes were subsequently transferred to $15 \mu \mathrm{g} / \mathrm{ml}$ bisbenzimide (Hoechst 33258) in DPBS for 15 min to permit labelling.

\section{Statistical analysis}

$\chi^{2}$ analysis was performed by comparing experimental groups with the control group for the numbers of fertilised and polyspermic embryos and unfertilised oocytes. A value of $P \leq 0.05$ was considered to be statistically significant.

\section{Acknowledgements}

This study was funded in full by the Centre for Reproduction at the Monash Institute of Medical Research. The authors declare that there is no conflict of interest that would prejudice the impartiality of this scientific work.

\section{References}

Alho AM \& Underhill CB 1989 The hyaluronate receptor is preferentially expressed on proliferating epithelial cells. Journal of Cell Biology 108 1557-1565.

Archibong AE, Petters RM \& Johnson BH 1989 Development of porcine embryos from one- and two-cell stages to blastocysts in culture medium supplemented with porcine oviductal fluid. Biology of Reproduction $\mathbf{4 1}$ 1076-1083.

Ax RL \& Ryan RJ 1979 The porcine ovarian follicle. IV. Mucopolysaccharides at different stages of development. Biology of Reproduction 20 $1123-1132$.

Bajorath J 2000 Molecular organization, structural features, and ligand binding characteristics of CD44, a highly variable cell surface glycoprotein with multiple functions. Proteins 39 103-111.

Bendahmane M, Zeng HT \& Tulsiani DR 2002 Assessment of acrosomal status in rat spermatozoa: studies on carbohydrate and non-carbohydrate agonists. Archives of Biochemistry and Biophysics 404 38-47.

Borland G, Ross JA \& Guy K 1998 Forms and functions of CD44. Immunology 93 139-148.

Bose N \& Masellis AM 2005 Secretory products of breast cancer cells upregulate hyaluronan production in a human osteoblast cell line. Clinical and Experimental Metastasis 22 629-642.

Bourguignon LY, Gilad E, Rothman K \& Peyrollier K 2005 Hyaluronan-CD44 interaction with IQGAP1 promotes Cdc42 and ERK signaling, leading to actin binding, Elk-1/estrogen receptor transcriptional activation, and ovarian cancer progression. Journal of Biological Chemistry $\mathbf{2 8 0}$ 11961-11972.

Bourguignon LY, Gilad E, Brightman A, Diedrich F \& Singleton P 2006 Hyaluronan-CD44 interaction with leukemia-associated RhoGEF and epidermal growth factor receptor promotes Rho/Ras co-activation, phospholipase $\mathrm{C}$ epsilon- $\mathrm{Ca}^{2+}$ signaling, and cytoskeleton modification in head and neck squamous cell carcinoma cells. Journal of Biological Chemistry 281 14026-14040.

Camaioni A, Hascall VC, Yanagishita M \& Salustri A 1993 Effects of exogenous hyaluronic acid and serum on matrix organization and stability in the mouse cumulus cell-oocyte complex. Journal of Biological Chemistry 268 20473-20481.

Camenisch TD, Schroeder JA, Bradley J, Klewer SE \& McDonald JA 2002 Heart-valve mesenchyme formation is dependent on hyaluronan-augmented activation of ErbB2-ErbB3 receptors. Nature Medicine 8 850-855.

Cherr GN, Yudin Al, Li MW, Vines CA \& Overstreet JW 1999 Hyaluronic acid and the cumulus extracellular matrix induce increases in intracellular calcium in macaque sperm via the plasma membrane protein $\mathrm{PH}-20$. Zygote 7 211-222.

Cohen DJ, Rochwerger L, Ellerman DA, Morgenfeld MM, Busso D \& Cuasnicu PS 2000 Relationship between the association of rat epididymal protein ' $D E^{\prime}$ with spermatozoa and the behavior and function of the protein. Molecular Reproduction and Development 56 180-188.

Cuasnicu PS, Conesa D \& Rochwerger L 1990 Potential contraceptive use of an epididymal protein that participates in fetilization. In Gamete Interaction: Prospects for Immunocontraception, pp 143-153. Eds NJ Alexander, D Griffin, JM Spieler \& GMH Waites. New York: Wiley-Liss.

Culty M, Miyake K, Kincade PW, Sikorski E, Butcher EC \& Underhill C 1990 The hyaluronate receptor is a member of the CD44 (H-CAM) family of cell surface glycoproteins. Journal of Cell Biology 111 2765-2774.

Dekel N \& Phillips DM 1979 Maturation of the rat cumulus oophorus. A scanning electron microscopic study. Biology of Reproduction 21 9-18.

Entwistle J, Hall CL \& Turley EA 1996 HA receptors: regulators of signalling to the cytoskeleton. Journal of Cellular Biochemistry 61 569-577.

Eppig JJ 1979 FSH stimulates hyaluronic acid synthesis by oocyte-cumulus cell complexes from mouse preovulatory follicles. Nature 281 483-484.

Eppig JJ 1981 Ovarian glycosaminoglycans: evidence for a role in regulating the response of the oocyte-cumulus cell complex to FSH. Endocrinology 108 1992-1994.

Eriksen GV, Malmstrom A, Uldbjerg N \& Huszar G 1994 A follicular fluid chondroitin sulfate proteoglycan improves the retention of motility and velocity of human spermatozoa. Fertility and Sterility 62 618-623.

Fulop C, Salustri A \& Hascall VC 1997 Coding sequence of a hyaluronan synthase homologue expressed during expansion of the mouse cumulus-oocyte complex. Archives of Biochemistry and Biophysics 337 261-266. 
Furnus CC, Valcarcel A, Dulout FN \& Errecalde AL 2003 The hyaluronic acid receptor (CD44) is expressed in bovine oocytes and early stage embryos. Theriogenology 60 1633-1644.

Goh HH, Yang XF, Tain CF, Liew LP \& Ratnam SS 1992 Oogenesis, fertilisation and early embryonic development in rats. II: Dose-dependent effects of human chorionic gonadotrophin. Annals of the Academy of Medicine of Singapore 21 451-458.

Gotoh M, Sato T, Akashima T, Iwasaki H, Kameyama A, Mochizuki H, Yada T, Inaba N, Zhang Y, Kikuchi N et al. 2002a Enzymatic synthesis of chondroitin with a novel chondroitin sulfate $\mathrm{N}$-acetylgalactosaminyltransferase that transfers $\mathrm{N}$-acetylgalactosamine to glucuronic acid in initiation and elongation of chondroitin sulfate synthesis. Journal of Biological Chemistry 277 38189-38196.

Gotoh M, Yada T, Sato T, Akashima T, Iwasaki H, Mochizuki H, Inaba T, Togayachi A, Kudo T, Watanabe $\mathbf{H}$ et al. $2002 b$ Molecular cloning and characterization of a novel chondroitin sulfate glucuronyltransferase that transfers glucuronic acid to $\mathrm{N}$-acetylgalactosamine. Journal of Biological Chemistry 277 38179-38188.

Green SJ, Tarone G \& Underhill CB 1988a Aggregation of macrophages and fibroblasts is inhibited by a monoclonal antibody to the hyaluronate receptor. Experimental Cell Research 178 224-232.

Green SJ, Tarone G \& Underhill CB 1988 b Distribution of hyaluronate and hyaluronate receptors in the adult lung. Journal of Cell Science $\mathbf{9 0}$ 145-156.

Hamamah S, Wittemer C, Barthelemy C, Richet C, Zerimech F, Royere D \& Degand P 1996 Identification of hyaluronic acid and chondroitin sulfates in human follicular fluid and their effects on human sperm motility and the outcome of in vitro fertilization. Reproduction, Nutrition, Development 36 $43-52$.

Hamashima N 1982 Effect of hyaluronic acid on the pre-implantation development of mouse embryo in vitro. Development, Growth and Differentiation 24 353-357.

Isacke CM 1994 The role of the cytoplasmic domain in regulating CD44 function. Journal of Cell Science 107 2353-2359.

Itano N, Atsumi F, Sawai T, Yamada Y, Miyaishi O, Senga T, Hamaguchi M \& Kimata K 2002 Abnormal accumulation of hyaluronan matrix diminishes contact inhibition of cell growth and promotes cell migration. PNAS 99 3609-3614.

Jang G, Lee BC, Kang SK \& Hwang WS 2003 Effect of glycosaminoglycans on the preimplantation development of embryos derived from in vitro fertilization and somatic cell nuclear transfer. Reproduction, Fertility, and Development 15 179-185.

Jensen CE \& Zachariae F 1958 Studies on the mechanism of ovulation: isolation and analysis of acid mucopolysaccharides in bovine follicular fluid. Acta Endocrinologica 27 356-368.

Josefsberg LB, Galiani D, Lazar S, Kaufman O, Seger R \& Dekel N 2003 Maturation-promoting factor governs mitogen-activated protein kinase activation and interphase suppression during meiosis of rat oocytes. Biology of Reproduction 68 1282-1290.

Kano K, Miyano T \& Kato S 1998 Effects of glycosaminoglycans on the development of in vitro-matured and -fertilized porcine oocytes to the blastocyst stage in vitro. Biology of Reproduction 58 1226-1232.

Kawakami E, Arai T, Oishi I, Hori T \& Tsutsui T 2000 Induction of dog sperm capacitation by glycosaminoglycans and glycosaminoglycan amounts of oviductal and uterine fluids in bitches. Journal of Veterinary Medical Science 62 65-68.

Kim KS, Foster JA \& Gerton GL 2001 Differential release of guinea pig sperm acrosomal components during exocytosis. Biology of Reproduction $\mathbf{6 4}$ 148-156.

Kim HS, Lee GS, Hyun SH, Nam DH, Lee SH, Jeong YW, Kim S, Kim JH, Kang SK, Lee BC et al. 2005 Embryotropic effect of glycosaminoglycans and receptors in development of porcine pre-implantation embryos. Theriogenology 63 1167-1180.

Kimura N, Konno Y, Miyoshi K, Matsumoto H \& Sato E 2002 Expression of hyaluronan synthases and CD44 messenger RNAs in porcine cumulusoocyte complexes during in vitro maturation. Biology of Reproduction $\mathbf{6 6}$ 707-717.

Kitagawa H, Uyama T \& Sugahara K 2001 Molecular cloning and expression of a human chondroitin synthase. Journal of Biological Chemistry 276 38721-38726

Kobayashi H, Suzuki M, Kanayama N, Nishida T, Takigawa M \& Terao T 2002 CD44 stimulation by fragmented hyaluronic acid induces upregulation of urokinase-type plasminogen activator and its receptor and subsequently facilitates invasion of human chondrosarcoma cells. International Journal of Cancer 102 379-389.

Kon J, Ooe H, Oshima H, Kikkawa Y \& Mitaka T 2006 Expression of CD44 in rat hepatic progenitor cells. Journal of Hepatology 45 90-98.

Kosaki R, Watanabe K \& Yamaguchi Y 1999 Overproduction of hyaluronan by expression of the hyaluronan synthase Has2 enhances anchorageindependent growth and tumorigenicity. Cancer Research 59 1141-1145.

Lee CN \& Ax RL 1984 Concentrations and composition of glycosaminoglycans in the female bovine reproductive tract. Journal of Dairy Science $\mathbf{6 7}$ 2006-2009.

Lee CN, Clayton MK, Bushmeyer SM, First NL \& Ax RL 1986 Glycosaminoglycans in ewe reproductive tracts and their influence on acrosome reactions in bovine spermatozoa in vitro. Journal of Animal Science 63 861-867.

Legg JW, Lewis CA, Parsons M, Ng T \& Isacke CM 2002 A novel PKCregulated mechanism controls $\mathrm{CD} 44$ ezrin association and directional cell motility. Nature Cell Biology 4 399-407.

Lenz RW, Ball GD, Lohse JK, First NL \& Ax RL 1983 Chondroitin sulfate facilitates an acrosome reaction in bovine spermatozoa as evidenced by light microscopy, electron microscopy and in vitro fertilization. Biology of Reproduction 28 683-690.

Lesley J \& Hyman R 1998 CD44 structure and function. Frontiers in Bioscience 3 d616-d630.

Lesley J, Hyman R \& Kincade PW 1993 CD44 and its interaction with extracellular matrix. Advance Immunology 54 271-335.

Liu D, Liu T, Li R \& Sy MS 1998 Mechanisms regulating the binding activity of CD44 to hyaluronic acid. Frontiers in Bioscience 3 d631-d636.

Lu DP, Tian L, O'Neill C \& King NJ 2002 Regulation of cellular adhesion molecule expression in murine oocytes, peri-implantation and postimplantation embryos. Cell Research 12 373-383.

Lugli A, Zlobec I, Gunthert U, Minoo P, Baker K, Tornillo L, Terracciano L \& Jass JR 2006 Overexpression of the receptor for hyaluronic acid mediated motility is an independent adverse prognostic factor in colorectal cancer. Modern Pathology 19 1302-1309.

Marchal R, Caillaud M, Martoriati A, Gerard N, Mermillod P \& Goudet G 2003 Effect of growth hormone $(\mathrm{GH})$ on in vitro nuclear and cytoplasmic oocyte maturation, cumulus expansion, hyaluronan synthases, and connexins 32 and 43 expression, and GH receptor messenger RNA expression in equine and porcine species. Biology of Reproduction 69 1013-1022.

Marhaba R, Bourouba M \& Zoller M 2005 CD44v6 promotes proliferation by persisting activation of MAP kinases. Cell Signalling 17 961-973.

Oh SH, Miyoshi K \& Funahashi R 1998 Rat oocytes fertilized in modified rat 1-cell embryo culture medium containing a high sodium chloride concentration and bovine serum albumin maintain developmental ability to the blastocyst stage. Biology of Reproduction 59 884-889.

Ohta N, Saito H, Kaneko T, Yoshida M, Takahashi T, Saito T, Nakahara K \& Hiroi M 2001 Soluble CD44 in human ovarian follicular fluid. Journal of Assisted Reproduction and Genetics 18 21-25.

Roscic-Mrkic B, Fischer M, Leemann C, Manrique A, Gordon CJ, Moore JP, Proudfoot AE \& Trkola A 2003 RANTES (CCL5) uses the proteoglycan CD44 as an auxiliary receptor to mediate cellular activation signals and HIV-1 enhancement. Blood 102 1169-1177.

Ruoslahti E \& Yamaguchi Y 1991 Proteoglycans as modulators of growth factor activities. Cell 64 867-869.

Sakai K, Kimata K, Sato T, Gotoh M, Narimatsu H, Shinomiya K \& Watanabe H 2007 Chondroitin sulfate $N$-acetylgalactosaminyltransferase1 plays a critical role in chondroitin sulfate synthesis in cartilage. Journal of Biological Chemistry 282 4152-4162.

Salustri A, Yanagishita M \& Hascall VC 1989 Synthesis and accumulation of hyaluronic acid and proteoglycans in the mouse cumulus cell-oocyte complex during follicle-stimulating hormone-induced mucification. Journal of Biological Chemistry 264 13840-13847.

Salustri A, Ulisse S, Yanagishita M \& Hascall VC 1990 Hyaluronic acid synthesis by mural granulosa cells and cumulus cells in vitro is selectively stimulated by a factor produced by oocytes and by transforming growth factor-beta. Journal of Biological Chemistry 265 19517-19523.

Salustri A, Yanagishita M, Underhill CB, Laurent TC \& Hascall VC 1992 Localization and synthesis of hyaluronic acid in the cumulus cells and mural granulosa cells of the preovulatory follicle. Developmental Biology 151 541-551. 
Sato E, Ishibashi T \& Koide SS 1987 Prevention of spontaneous degeneration of mouse oocytes in culture by ovarian glycosaminoglycans. Biology of Reproduction 37 371-376.

Sato E, Kawamura N \& Ishibashi T 1988 Chemicals influencing maturation, activation, and degeneration of bovine oocytes in culture. Journal of Dairy Science 71 3482-3488.

Sato E, Inoue M, Takahashi Y \& Toyoda Y 1994 Glycosaminoglycans prevent induction of fragmentation of porcine oocytes stimulated by dibutyryl cyclic adenosine $3^{\prime}, 5^{\prime}$-monophosphate in culture. Cell Structure and Function 19 29-36.

Sato T, Gotoh M, Kiyohara K, Kameyama A, Kubota T, Kikuchi N, Ishizuka Y, Iwasaki H, Togoyachi A, Kudo T et al. 2003 Molecular cloning and characterization of a novel human beta 1,4-N-acetylgalactosaminyltransferase, beta 4GalNAc-T3, responsible for the synthesis of $N, N^{\prime}$ diacetyllactosediamine, galNAc beta 1-4GlcNAc. Journal of Biological Chemistry 278 47534-47544.

Schoenfelder M \& Einspanier R 2003 Expression of hyaluronan synthases and corresponding hyaluronan receptors is differentially regulated during oocyte maturation in cattle. Biology of Reproduction 69 269-277.

Screaton GR, Bell MV, Jackson DG, Cornelis FB, Gerth U \& Bell Jl 1992 Genomic structure of DNA encoding the lymphocyte homing receptor CD44 reveals at least 12 alternatively spliced exons. PNAS89 12160-12164.

Shi M, Dennis K, Peschon JJ, Chandrasekaran R \& Mikecz K 2001 Antibodyinduced shedding of CD44 from adherent cells is linked to the assembly of the cytoskeleton. Journal of Immunology 167 123-131.

Shi X, Leng L, Wang T, Wang W, Du X, Li J, McDonald C, Chen Z, Murphy JW, Lolis E et al. 2006 CD44 is the signaling component of the macrophage migration inhibitory factor-CD74 receptor complex. Immunity 25 595-606.

Silbert JE \& Freilich LS 1980 Biosynthesis of chondroitin sulphate by a Golgiapparatus-enriched preparation from cultures of mouse mastocytoma cells. Biochemical Journal 190 307-313.

Singh R, Subramanian S, Rhodes JM \& Campbell BJ 2006 Peanut lectin stimulates proliferation of colon cancer cells by interaction with glycosylated CD44v6 isoforms and consequential activation of c-Met and MAPK: functional implications for disease-associated glycosylation changes. Glycobiology 16 594-601.

Spicer AP, Olson JS \& McDonald JA 1997a Molecular cloning and characterization of a cDNA encoding the third putative mammalian hyaluronan synthase. Journal of Biological Chemistry 272 8957-8961.

Spicer AP, Seldin MF et al. 1997b Chromosomal localization of the human and mouse hyaluronan synthase genes. Genomics 41 493-497.

Suchanek E, Simunic V, Juretic D \& Grizelj V 1994 Follicular fluid contents of hyaluronic acid, follicle-stimulating hormone and steroids relative to the success of in vitro fertilization of human oocytes. Fertility and Sterility $\mathbf{6 2}$ 347-352.

Therien I, Bergeron A, Bousquet D \& Manjunath P 2005 Isolation and characterization of glycosaminoglycans from bovine follicular fluid and their effect on sperm capacitation. Molecular Reproduction and Development 71 97-106.

Tolg C, Hofmann M, Herrlich P \& Ponta H 1993 Splicing choice from ten variant exons establishes CD44 variability. Nucleic Acids Research 21 $1225-1229$

Toyoda Y \& Chang MC 1974 Fertilization of rat eggs in vitro by epididymal spermatozoa and the development of eggs following transfer. Journal of Reproduction and Fertility 36 9-22.
Toyokawa K, Harayama H \& Miyake M 2005 Exogenous hyaluronic acid enhances porcine parthenogenetic embryo development in vitro possibly mediated by CD44. Theriogenology 64 378-392.

Uyama T, Kitagawa H, Tamura Ji J \& Sugahara K 2002 Molecular cloning and expression of human chondroitin $\mathrm{N}$-acetylgalactosaminyltransferase: the key enzyme for chain initiation and elongation of chondroitin/dermatan sulfate on the protein linkage region tetrasaccharide shared by heparin/heparan sulfate. Journal of Biological Chemistry 277 8841-8846.

Wade MA, Roman SD, Jones RC \& Aitken RJ 2003 Adenylyl cyclase isoforms in rat testis and spermatozoa from the cauda epididymidis. Cell and Tissue Research 314 411-419.

Watanabe K \& Yamaguchi Y 1996 Molecular identification of a putative human hyaluronan synthase. Journal of Biological Chemistry 271 22945-22948.

Weigel PH, Hascall VC \& Tammi M 1997 Hyaluronan synthases. Journal of Biological Chemistry 272 13997-14000.

Whittingham DG 1971 Culture of mouse ova. Journal of Reproduction and Fertility 14 (Supplement) 7-21.

Yada T, Gotoh M, Sato T, Shionyu M, Go M, Kaseyama H, Iwasaki H, Kikuchi N, Kwon YD, Togayachi A et al. 2003a Chondroitin sulfate synthase-2. Molecular cloning and characterization of a novel human glycosyltransferase homologous to chondroitin sulfate glucuronyltransferase, which has dual enzymatic activities. Journal of Biological Chemistry 278 30235-30247.

Yada T, Sato T, Kaseyama H, Gotoh M, Iwasaki H, Kikuchi N, Kwon YD, Togayachi A, Kudo T, Watanabe H et al. 2003b Chondroitin sulfate synthase-3. Molecular cloning and characterization. Journal of Biological Chemistry 278 39711-39725.

Yanagishita M \& Hascall VC 1979 Biosynthesis of proteoglycans by rat granulosa cells cultured in vitro. Journal of Biological Chemistry 254 12355-12364.

Yanagishita M, Rodbard D \& Hascall VC 1979 Isolation and characterization of proteoglycans from porcine ovarian follicular fluid. Journal of Biological Chemistry 254 911-920.

Yokoo M, Miyahayashi Y, Naganuma T, Kimura N, Sasada H \& Sato E 2002a Identification of hyaluronic acid-binding proteins and their expressions in porcine cumulus-oocyte complexes during in vitro maturation. Biology of Reproduction 67 1165-1171.

Yokoo M, Tientha P, Kimura N, Niwa K, Sato E \& Rodriguez-Martinez H $2002 b$ Localisation of the hyaluronan receptor CD44 in porcine cumulus cells during in vivo and in vitro maturation. Zygote 10 317-326.

Yokoo M, Shimizu T, Kimura N, Tunjung WA, Matsumoto $\mathbf{H}$, Abe $\mathbf{H}$, Sasada H, Rodriguez-Martinez H \& Sato E 2007 Role of the hyaluronan receptor CD44 during porcine oocyte maturation. Journal of Reproduction and Development 53 263-270.

Received 13 June 2007

First decision 6 September 2007

Revised manuscript received 16 October 2007

Accepted 31 October 2007 